\title{
ANALISIS ANALISIS KONTRIBUSI PAJAK KENDARAAN BERMOTOR DAN BEA BALIK NAMA KENDARAAN BERMOTOR DALAM MENINGKATKAN PENDAPATAN ASLI DAERAH DI PROVINSI SULAWESI TENGGARA
}

\author{
Oleh \\ Ishak Awaluddin ${ }^{1}$, Sulvariany Tamburaka ${ }^{2}$, Muh. Ibrahim ${ }^{3}$ \\ Jurusan Akuntansi Fakultas Ekonomi dan Bisnis Universitas Halu Oleo Kendari \\ Sulawesi Tenggara
}

\begin{abstract}
ABSTRAK
Penelitian ini bertujuan untuk mengetahui dan menganalisis kontribusi pajak kendaraan bermotor dan bea balik nama kendaraan bermotor dalam meningkatkan pendapatan asli daerah di Provinsi Sulawesi Tenggara. Data yang digunakan adalah data primer dan sekunder dengan metode pengumpulan data dalam penelitian ini yaitu wawancara dan dokumentasi. Analisis data yang digunakan analisis deskriptif. Hasil penelitian ini menunjukan bahwa (1) penerimaan realisasi pajak kendaraan bermotor di Provinsi Sulawesi Tenggara tahun 2016-2019 memberikan kontribusi dengan rata-rata yaitu $14,95 \%$ termasuk dalam kriteria kurang, hal ini disebabkan karena kurangnya kesadaran wajib pajak terhadap pembayaran pajak kendaraan, terjadinya penurunan di jenis-jenis kendaraan dan kurang optimalnya pelayanan yang diberikan oleh setiap UPTB SAMSAT wilayah yang ada di Provinsi Sulawesi Tenggara (2) realisai untuk bea balik nama kendaraan bermotor tahun 2016-2019 yaitu berkontribusi dengan rata-rata 26,16\% termasuk dalam kriteria sedang.
\end{abstract}

Kata Kunci : Kontribusi, Pajak Kendaraan Bermotor, Bea Balik Nama Kendaraan Bermotor, Pendapatan Asli Daerah

The research aims to analyze the contributions of the motor vehicle tax contribution and the motor vehicle registration of duty in increasing the local own source revenue in southeast Sulawesi province. The data used is primary and secondary data with the method of data collection in this research i.e. interviews and documentation. Adata instinctively utilized descriptive analysis. The results of this study indicate that (1) the Realization of the income tax of motor vehicle in southeast Sulawesi Province in 2016-2019 contributes with the average of $14.95 \%$ included in the criteria less, this is due to a lack of taxpayer awareness of the payment of vehicle taxes, the occurrence of decline in vehicle types and less optimal service provided by each UPTB Samsat region in southeast Sulawesi Province (2) Realization for the customs name of the motor vehicle year 2016-2019 is contributing with an average of $26.16 \%$ included in medium criteria.

Keywords : Contributions, Motor Vehicle Tax, Customs Name Of Motor Vehicle, Indigenous Revenue Region

\section{PENDAHULUAN}

Pelaksanaan otonomi daerah pada hakikatnya memberi peluang yang lebih besar kepada daerah untuk dapat mengoptimalisasi potensi-potensi yang ada di daerah tersebut. Daerah otonomi harus memiliki kemampuan untuk menggali sumber-sumber keuangannya sendiri, mengelola dan menggunakannya untuk membiayai penyelangaraan pemerintah daerahnya. Setiap daerah mempunyai kewajiban untuk memenuhi kepentingan masyarakat dengan cara melaksanakan pembangunan daerah disegala bidang. Sumber-sumber pembiayaan untuk melaksanakan pembangunan tersebut salah satunya adalah bersumber dari pendapatan asli daerah. 
Pendapatan Asli Daerah (PAD) merupakan semua penerimaan daerah yang berasal dari sumber ekonomi asli daerah (Halim, 2004:67). Pendapatan daerah juga merupakan pendapatan yang diperoleh oleh pemerintah daerah dan digali dari potensi pendapatan yang ada pada daerah. Dengan kata lain pendapatan asli daerah merupakan pendapatan yang diterima oleh pemerintah daerah atas segala sumber-sumber atau potensi yang ada pada daerah yang harus diolah oleh pemerintah daerah di dalam memperoleh pendapatan daerah Pajak daerah digolongkan menjadi dua, yaitu : pajak daerah tingkat Provinsi seperti Pajak Kendaraan Bermotor (PKB), Bea Balik Nama Kendaraan Bermotor (BBN-KB) dan lainlain. Sedangkan pajak daerah tingkat Kabupaten/Kota seperti pajak hotel, pajak restoran, pajak reklame dan lain-lain.

Dari sekian banyak jenis pajak daerah, salah satu jenis pajak yang sumber pendapatannya cukup besar adalah Pajak Kendaraan Bermotor (PKB). Seperti yang telah diatur dalam pasal 1 ayat 12 undang-undang Nomor 28 tahun 2009 pajak kendaraan bermotor adalah pajak atas kepemilikan dan/atau penguasaan kendaraan bermotor. Kendaraan bermotor adalah semua kendaraan beroda atau lebih beserta gandengannya yang digunakan disemua jenis jalan darat, dan digerakkan oleh peralatan teknik berupa motor atau peralatan lainnya yang berfungsi untuk mengubah suatu sumber daya energi tertentu menjadi tenaga gerak, termasuk alat-alat berat dan alat-alat besar yang dalam operasinya menggunakan roda dan tidak melekat secara permanen serta kendaraan bermotor yang dioperasikan diair. Selain itu seperti yang telah diatur pasal 1 ayat 4 Permendagri Nomor 12 tahun 2016 Pajak Bea Balik Nama Kendaraan Bermotor yang selanjutnya disingkat BBNKB merupakan pajak atas penyerahan hak milik kendaraan bermotor sebagai akibat perjanjian dua pihak atau perbuatan sepihak atau keadaan yang terjadi karena jual beli, tukar menukar, hibah, warisan, atau pemasukan ke dalam badan usaha.

Pertumbuhan penggunaan kendaraan bermotor terus mengalami peningkatan tiap tahunnya, dilihat dari banyaknya masyarakat yang lebih memilih menggunakan kendaraan pribadi dari pada kendaraan umum dalam menjalankan aktivitas. Hal ini juga disebabkan karena begitu mudahnya masyarakat dalam memperoleh atau mendapatkan kendaraan bermotor yang mereka inginkan, karena banyaknya kemudahan dari dealer yang memberikan kemudahan kredit yang menguntungkan bagi pembeli.

Dengan munculnya berbagai kebijakan tersebut, maka semakin banyak masyarakat yang tertarik untuk membeli kendaraan bermotor. Apalagi sarana transportasi merupakan salah satu faktor penting dalam menjalankan roda perekonomian, dimana transportasi dapat membantu aktivitas perekonomian menjadi lebih efesian. Untuk daerah Sulawesi Tenggara itu sendiri banyak masyarakat yang lebih memilih menggunakan transportasi dalam menjalankan aktivitas sehari-hari. Dengan bertambahnya jumlah pemakai kendaraan bermotor tentunya akan menjadi keuntungan bagi pemerintah daerah dalam penerimaan pajak kendaraan bermotor dan pajak bea balik nama kendaraan bermotor. Peningkatan jumlah objek kendaraan bermotor serta realisasi penerimaan PKB dan BBNKB dapat dilihat pada Tabel 1 berikut ini.

Tabel 1. Jumlah Objek Kendaraan Bermotor, Target dan Realisai Penerimaan

Pajak Kendaraan Bermotor dan Bea Balik Nama Kendaraan Bermotor di Provinsi Sulawesi Tenggara Tahun 2016-2019

\begin{tabular}{|c|c|c|c|c|c|c|c|}
\hline \multirow{2}{*}{ Thn } & \multirow{2}{*}{$\begin{array}{c}\text { Jumlah } \\
\text { Kendaraan } \\
\text { Bermotor }\end{array}$} & \multicolumn{3}{|c|}{ Penerimaan PKB (000 Rp) } & \multicolumn{3}{|c|}{ Penerimaan BBNKB (000 Rp) } \\
\hline & & Target & Realisasi & $(\%)$ & Target & Realisasi & $(\%)$ \\
\hline 2016 & 208.714 & $86.341 .000,-$ & 101.543.198,- & 117,61 & 157.544.781,- & $205.657,773,-$ & 130,54 \\
\hline 2017 & 240.420 & $95.569 .000,-$ & 140.367.041,-- & 146,88 & 197.556.000,- & 176.824.691,- & 89,51 \\
\hline 2018 & 273.115 & $105.000 .000,-$ & 133.828.181,-- & 127,46 & $200.000 .000,-$ & 253.114.069,- & 126,56 \\
\hline 2019 & 331.132 & 139.006.700,- & 159.128.482,-- & 114,48 & $279.427 .500,-$ & 306.552.747,- & 109,71 \\
\hline
\end{tabular}


Tabel 1.1 di atas menunjukan bahwa jumlah objek kendaraan bermotor di Provinsi Sulawesi Tenggara dari tahun 2016-2019 selalu mengalami peningkatan dalam empat tahun terakhir. Dilihat dari jumlah kendaraan bermotor pada tahun 2016 sebanyak 208.714 lalu meningkat sebanyak 240.420 pada tahun 2017. Di tahun 2018 terus meningkat yaitu 273.115. Dan di tahun 2019 kembali mengalami peningkatan sebanyak 331.132. Dengan meningkatnya jumlah objek kendaraan bermotor tentu akan memberikan kontribusi pada penerimaan pajak kendaraan bermotor dan bea balik nama kendaraan bermotor di Provinsi Sulawesi Tenggara tahun 2016-2019.

Jumlah target dan realisasi penerimaan pajak kendaraan bermotor di Provinsi Sulawesi Tenggara dari tahun 2016 sampai 2019 sudah mencapai target yang telah ditentukan pada setiap tahunnya. Namun jika dilihat dari realisasi dan persentasenya dimana 2016 realisasi yang di capai sebesar Rp.101.543.198.517 dengan persentase 117,61\%. Lalu meningkat pada tahun 2017 sebesar Rp.140.367.041.211 dengan persentase 146,88\%. Pada tahun 2018 sedikit mengalami penurunan realisasi yang hanya memperoleh Rp.133.828.181.973 dengan persentasenya 127,46\%. Dan kembali mengalami peningkatan pada tahun 2019 dengan penerimaan realisasi Rp. 159.128.482.191 dengan persentase 114,48 .

Sedangkan dari data target dan realisasi penerimaan bea balik nama kendaraan bermotor di Provinsi Sulawesi Tenggara mengalami penurunan realisasi atau tidak mencapai target yang dicanangkan yang terjadi di tahun 2017. Terlihat pada penerimaan realisasi di tahun 2016 sebesar Rp.205.657.773.961 dengan persentase 130,54\%. Dan di tahun 2017 mengalami penurunan yaitu sebesar Rp.176.824.691.492 dengan persentase 89,51\%. Namun di tahun 2018 kembali meningkat sebesar Rp.253.144.096.500 dengan persentase 126,56\%. Peningkatan penerimaan realisasi terus meningkat pada tahun 2019 yaitu sebesar Rp.306.552.747.357 dengan persenatse 109,71\%. Hal ini menunjukan bahwa dalam penerimaan realisasi Pajak Kendaraan Bermotor (PKB) dan Bea Balik Nama Kendaraan Bermotor (BBNKB) masih belum optimal, realisasi pajak kendaraan bermotor dan bea balik nama kendaraan bermotor yang belum optimal dapat memberikan kontribusi yang rendah terhadap Pendapatan Asli Daerah. Penelitian ini bertujuan untuk mengetahui dan menganalisis kontribusi pajak kendaraan bermotor dan bea balik nama kendaraan bermotor dalam meningkatkan pendapatan asli daerah di Provinsi Sulawesi Tenggara tahun 2016-2019.

\section{Pajak}

\section{TINJAUAN PUSTAKA}

Menurut Rochman Soemitro Pajak adalah iuran rakyat kepada kas negara berdasarkan undang-undang (yang dapat dipaksakan) dengan tidak mendapat jasa timbal (Kontraprestasi) yang langsung dapat ditunjukan dan digunakan untuk membayar pengeluaran umum P.J.A. Andriani (Waluyo 2011:2) Pajak adalah iuran kepada negara (yang dapat dipaksakan) yang terutang oleh yang wajib membayarnya menurut peraturan peraturan, dengan tidak mendapat prestasi kembali, yang langsung dapat di tunjuk, dan yang gunanya adalah untuk membiayai pengeluaran-pengeluaran umum berhubungan dengan tugas negara yang menyelenggarakan pemerintah. Siti resmi (2019:2) Dari definisi diatas, dapat disimpulkan bahwa pajak memiliki unsur-unsur, antara lain :

1. Pajak dipungut berdasarkan atau dengan kekuatan undang-undang serta aturan pelaksanaannya.

2. Dalam pembayaran pajak tidak dapat ditunjukan adanya kontraprestasi individual oleh pemerintah.

3. Pajak dipungut oleh Negara baik pemerintah pusat maupun pemerintah daerah. 


\section{Pajak daerah}

Daerah di Indonesia berdasarkan Undang - undang No. 28 Tahun 2009 terbagi menjadi dua, yaitu Pajak Provinsi dan Pajak Kabupaten/Kota. Pembagian ini dilakukan sesuai dengan kewenangan pengenaan dan pemungutan masing-masing jenis pajak daerah pada wilayah administrasi provinsi atau kabupaten/kota yang bersangkutan.

Pajak daerah menurut Mardiasmo (2016:14) adalah kontribusi wajib kepada Daerah yang terutang oleh orang pribadi atau badan yang bersifat memaksa berdasarkan undangundang, dengan tidak mendapatkan imbalan secara langsung dan digunakan untuk keperluan Daerah bagi sebesar-besarnya kemakmuran rakyat. Pajak.

Berdasarkan Peraturan Daerah Provinsi Sulawesi Tenggara No. 4 tahun 2019 Pasal 2 disebutkan bahwa jenis pajak daerah yaitu :

a. Pajak daerah tingkat Provinsi :

1. Pajak kendaraan bermotor

2. Pajak bea baik nama kendaraan bermotor

3. Pajak bahan bakar kendaraan bermotor

4. Pajak air permukaan dan

5. Pajak rokok

b. Pajak daerah tingkat Kabupaten/Kota :

1. Pajak hotel

2. Pajak restoran

3. Pajak hiburan

4. Pajak reklame

5. Pajak penerangan jalan

6. Pajak mineral bukan logam dan batuan

7. Pajak parkir

8. Pajak air tanah

9. Pajak sarang burung wallet

10. Pajak Bea Perolehan Hak atas Tanah dan Bangunan

11. Pajak Bumi dan Bangunan pedesaan dan perkotaan

\section{Pajak Kendaraan Bermotor (PKB)}

Peraturan Daerah Provinsi Sulawesi Tenggara nomor 4 tahun 2019 pasal 1 menyatakan bahwa pajak kendaraan bermotor yang selanjutnya disingkat PKB adalah pajak atas kepemilikan dan/atau penguasaan kendaraan bermotor. Sebagaimana juga yang telah di atur dalam pasal 1 ayat (12) Undang-undang nomor 28 tahun 2009 pajak kendaraan bermotor merupakan pajak atas kepemilikan dan/atau penguasaan kendaraan bermotor. Kendaraan bermotor adalah semua kendaraan beroda atau lebih beserta gandengannya yang digunakan di semua jenis jalan darat, dan digerakkan oleh peralatan teknik berupa motor atau peralatan lainnya yang berfungsi untuk mengubah suatu sumber daya energi tertentu menjadi tenaga gerak, termasuk alat-alat berat dan alat-alat besar yang dalam operasinya menggunakan roda dan tidak melekat secara permanen serta kendaraan bermotor yang di operasikan di air.

Dasar hukum Pajak Kendaraan Bermotor diatur sebagaimana berikut ini :

1. Undang-Undang Nomor 28 tahun 2009 tentang Pajak Daerah dan Retribusi Daerah.

2. Peraturan Daerah Provinsi Sulawesi Tenggara Nomor 4 Tahun 2019 tentang Pajak Daerah.

3. Peraturan Gubernur Sulawesi Tenggara Nomor 10 Tahun 2019 tentang tata cara penyaluran dana bagi hasil pajak Provinsi kepada pemerintah Kabupaten/Kota. 
Jurnal Akuntansi dan Keuangan (JAK)

Volume 6, No. 1 Februari Tahun 2021

Page: 268 - 271

http://ojs.uho.ac.id/index.php/jak-uho/issue/archive

e-ISSN: 2088-4656

4. Peraturan Menteri Dalam Negeri Nomor 2 tahun 2006 tentang Perhitungan dasar pengenanan pajak kendaraan bermotor dan bea balik nama kendaraan bermotor tahun 2006.

5. Peraturan Gubernur yang mengatur tentang PKB sebagai aturan pelaksanaan peraturan daerah tentang PKB pada provinsi yang dimaksud.

\section{Bea Balik Nama Kendaraan Bermotor (BBNKB)}

Berdasarkan Peraturan Daerah Provinsi Sulawesi Tenggara nomor 4 tahun 2019

Pasal 1 menyatakan bahwa Bea Balik Nama Kendaraan Bermotor yang selanjutnya disingkat BBNKB adalah pajak atas penyerahan hak milik kendaraan bermotor sebagai akibat perjanjian dua pihak atau perbuatan sepihak atau keadaan yang terjadi karena jual beli, tukar menukar, hibah, warisan, atau pemasukan ke dalam badan usaha.

\section{Pendapatan Asli Daerah (PAD)}

Pasal 1 dalam Undang-undang Nomor 33 Tahun 2004 tentang perimbangan keuangan antar pusat dan daerah, Pendapatan Asli Daerah adalah penerimaan yang di peroleh dari sumber-sumber di dalam daerah yang di pungut berdasarkan peraturan daerah sesuai dengan peraturan perundang- undangan yang berlaku. Dengan kata lain pendapatan asli daerah merupakan pendapatan yang diterima oleh pemerintah daerah atas segala sumber-sumber atau potensi yang ada pada daerah yang harus diolah oleh pemerintah daerah di dalam memperoleh pendapatan daerah.

Menurut Halim (2004:67) pengertian pendapatan asli daerah yaitu "Pendapatan Asli Daerah merupakan semua penerimaan daerah yang berasal dari sumber ekonomi asli daerah". Dalam Undang-undang No.32 tahun 2004 disebutkan bahwa pendapatan asli daerah bersumber dari berikut ini :

1. Pajak daerah

2. Retribusi daerah

3. Perusahaan daerah

4. Lain-lain Pendapatan daerah yang sah

\section{Kontribusi}

Kontribusi merupakan dukungan, sumbangan dalam bentuk ide, tenaga, ataupun benda. Dalam bahasa inggris contribus atau contribution artinya menyumbang. Dapat di artikan pula kontribusi merupakan dukungan yang diberikan kepada pihak atau kumpulan untuk mencapai tujuan akhir yang merupakan suatu cerminan seberapa besar bentuk dukungan diterima.

Mahmudi (2010:145) "kontribusi digunakan untuk mengetahui sejauh mana pajak daerah memberikan sumbangan dalam penerimaan Pendapatan Asli Daerah (PAD)".

Untuk mengetahui kontribusi dilakukan dengan menghitung penerimaan realisasi PKB dan BBNKB periode tertentu dengan penerimaan realisasi PAD periode tertentu pula. pengukuran kontribusi di lakukan dengan rumus sebagai berikut :

Kontribusi $=\frac{\text { Realisasi Pajak Kendaraan Bermotor }}{\text { Realisasi Pendapatan Asli Daerah }} \times 100 \%$

Sumber : Handoko (2013:3) 
Jurnal Akuntansi dan Keuangan (JAK)

Volume 6, No. 1 Februari Tahun 2021

Page: 268 - 271

http://ojs.uho.ac.id/index.php/jak-uho/issue/archive

e-ISSN: 2088-4656

Adapun kriteria yang digunakan dalam menilai kontribusi adalah :

Tabel 2 Klasifikasi Kontribusi

\begin{tabular}{|l|l|}
\hline \multicolumn{1}{|c|}{ Persentase } & \multicolumn{1}{c|}{ Kriteria } \\
\hline $0,00 \%-10 \%$ & Sangat Kurang \\
\hline $10,00 \%-20 \%$ & Kurang \\
\hline $20,00 \%-30 \%$ & Sedang \\
\hline $30,00 \%-40 \%$ & Cukup Baik \\
\hline $40,00 \%-50 \%$ & Baik \\
\hline Diatas $50 \%$ & Sangat Baik \\
\hline
\end{tabular}

Sumber : Abdul Halim (2008:233)

\section{METODE PENELITIAN}

Penelitian ini bertempat di Badan Pendapatan Daerah (BAPENDA) Provinsi Sulawesi Tenggara yang beralamat di Jl. Haluoleo, Anduonohu, Kota Kendari, Provinsi Sulawesi Tenggara. Objek dari Penelitian ini adalah kontribusi Pajak Kendaraan Bermotor (PKB) dan Bea Balik Nama Kendaraan Bermotor (BBNKB) dalam meningkatkan Pendapatan Asli Daerah (PAD) di Provinsi Sulawesi Tenggara. Jenis data yang digunakan dalam penelitian ini yaitu data kualitatif dan data kuantitatif. Data kualitatif dalam penelitian ini yaitu berupa gambaran umum tentang instansi, data tentang peraturan pemerintah daerah mengenai $\mathrm{PKB}$ dan BBNKB, Struktur organisasi dan keteranganketerangan lainnya yang di peroleh dari wawancara dengan pihak instansi terkait, dalam halam ini BAPENDA Prov. Sultra. Data kuantitatif dalam penelitian ini yaitu data yang di peroleh dalam bentuk angka-angka yang mempunyai relevasi dalam penelitian ini seperti, laporan target dan realisasi penerimaan $\mathrm{PKB}$, target dan realisasi penerimaan BBNKB serta target dan realisasi penerimaan PAD di Provinsi Sulawesi Tenggara tahun 2016-2019.

Sumber data yang digunakan dalam penelitian ini menggunakan data primer dan data sekunder. Data primer diperoleh penulis dari informan atau partisipan melalui wawancara langsung dengan pegawai Badan Pendapatan Daerah (BAPENDA) di Provinsi Sulawesi Tenggara. Sedangkan data sekunder dalam penelitian ini adalah sumber data terkait pajak kendaraan bermotor dan bea balik nama kendaraan bermotor yang di peroleh berupa dokumen atau arsip target dan realisasi PKB, BBNKB dan jumlah objek pajak kendaraan bermotor pada Badan Pendapatan Daerah (BAPENDA) di Provinsi Sulawesi Tenggara tahun 2016-2019.

Teknik pengumpulan data dalam penelitian adalah dokumenasi dan wawancara. Dokumentasi dalam penelitian ini berupa dokumen profil BAPENDA Provinsi Sulawesi Tenggara yang mencakup visi, misi daftar staf pengelolan, serta dokumen pembukuan dan pelaporan $\mathrm{PKB}, \mathrm{BBNKB}$ dan $\mathrm{PAD}$ seperti data target dan realisasi penerimaan pajak di Provinsi Sulawesi Tenggara dari tahun 2016-2019. Wawancara dalam penelitian ini berupa tanya jawab secara langsung dengan mengajukan secara langsung pertanyaan-pertanyaan kepada pihak yang berwenang di BAPENDA Provinsi Sulawesi Tenggara yaitu Kepala Sub Bidang (KASUBID) bagian pendataan dan pengenaan pajak atas nama Bapak La Ode Mahbub, S.,Sos. Dengan maksud untuk memperoleh data baik secara lisan maupun secara tulisan.

Metode yang digunakan dalam penelitian ini adalah metode analisis deskriptif. Metode analisis deskriptif yaitu suatu metode analisis yang digunakan dengan mengumpulkan dan mengklasifikasi data yang sudah ada, kemudian menganalisis data dan mendeskripsikan sehingga memberikan suatu gambaran yang sebenarnya, baik itu data-data mengenai target dan realisasi PKB, BBNKB dan PAD. Adapun tahapannya adalah sebagai berikut : 
1. Mengumpulkan data-data yang diperoleh dari BAPENDA Prov. Sultra berupa data target dan realisasi Penerimaan PKB, BBNKB dan PAD dari tahun 2016-2019.

2. Melakukan wawancara.

3. Melakukan Analisis Penerimaan realisasi PKB dan BBNKB dengan rumus

\begin{tabular}{|c|c|}
\hline Kontribusi $=\frac{\text { Realisasi Pajak Kendaraan Bermotor }}{\text { Realisasi Pendapatan Asli Daerah }}$ & x 100\% \\
Kealisasi Bea Balik Nama Kendaraan Bermotor & x 100\% \\
Kentribusi $=$ Realisasi Pendapatan Asli Daerah & \\
\hline
\end{tabular}

Sumber : Handoko (2013:3)

4. Pengukuran Klasifikasi Kontribusi.

Tabel 3 Klasifikasi Kontribusi

\begin{tabular}{|l|l|}
\hline \multicolumn{1}{|c|}{ Persentase } & \multicolumn{1}{c|}{ Kriteria } \\
\hline $0,00 \%-10 \%$ & Sangat Kurang \\
\hline $10,00 \%-20 \%$ & Kurang \\
\hline $20,00 \%-30 \%$ & Sedang \\
\hline $30,00 \%-40 \%$ & Cukup Baik \\
\hline $40,00 \%-50 \%$ & Baik \\
\hline Diatas $50 \%$ & Sangat Baik \\
\hline
\end{tabular}

Sumber : Abdul Halim ( 2008:233)

5. Menarik kesimpulan penelitian.

\section{HASIL DAN PEMBAHASAN}

Hasil Penelitian

Berdasarkan hasil analisis data menunjukkan bahwa :

Tabel 4 Kontribusi Pajak Kendaraan Bermotor (PKB) dalam meningkatkan

Pendapatan Asli Daerah (PAD) di Provinsi Sulawesi Tenggara Tahun 2016-2019

\begin{tabular}{|l|c|c|l|l|}
\hline Tahun & $\begin{array}{c}\text { Realisasi PKB } \\
(\mathbf{R p})\end{array}$ & $\begin{array}{c}\text { Realisasi PAD } \\
(\mathbf{R p )}\end{array}$ & Kontribusi & Kriteria \\
\hline $\mathbf{2 0 1 6}$ & 101.543 .198 .517 & 753.658 .254 .463 & $13,48 \%$ & Kurang \\
\hline $\mathbf{2 0 1 7}$ & 140.367 .041 .211 & 806.253 .869 .893 & $17,41 \%$ & Kurang \\
\hline $\mathbf{2 0 1 8}$ & 133.828 .181 .973 & 903.949 .000 .785 & $14,80 \%$ & Kurang \\
\hline $\mathbf{2 0 1 9}$ & 159.128 .482 .191 & 1.128 .814 .985 .406 & $14,09 \%$ & Kurang \\
\hline \multicolumn{2}{l}{} & & $14,95 \%$ & Kurang \\
\hline
\end{tabular}

Sumber : Badan Pendapatan Daerah, Badan Pengelola Keuangan dan aset Daerah Provinsi Sulawesi Tenggara, Data diolah 2020

Tabe di atas dapat dilihat bahwa kontribusi PKB dalam meningkatkan PAD di Provinsi Sulawesi Tenggara pada tahun 2016 PKB memberikan kontribusi sebesar 13,48\% dengan kriteria kurang, tahun 2017 penerimaan PKB mengalami peningkatan dengan berkontribusi sebesar 17,41\%, tahun 2018 pajak kendaraan bermotor mengalami penurun kontribusi sebesar 14,80\% termasuk dalam kriteria kurang, Sedangkan pada tahun 2019 kontribusi yang diberikan sebesar 14,09\% termasuk dalam kriteria kurang. 
Tabel 5 Kontribusi Bea Balik Nama Kendaraan Bermotor (BBNKB) dalam meningkatkan Pendapatan Asli Daerah (PAD) di Provinsi Sulawesi Tenggara Tahun 2016-2019

\begin{tabular}{|c|c|c|c|c|}
\hline Tahun & $\begin{array}{c}\text { Realisasi BBNKB } \\
\text { (Rp) }\end{array}$ & $\begin{array}{l}\text { Realisasi PAD } \\
\text { (Rp) }\end{array}$ & Kontribusi & Kriteria \\
\hline 2016 & 205.657 .773 .961 & 753.658 .254 .463 & $27,29 \%$ & Sedang \\
\hline 2017 & 176.824 .691 .492 & 806.253 .869 .893 & $22,18 \%$ & Sedang \\
\hline 2018 & 253.114 .096 .500 & 903.949 .000 .785 & $28,00 \%$ & Sedang \\
\hline 2019 & 306.552 .747 .357 & 1.128 .814 .985 .406 & $27,15 \%$ & Sedang \\
\hline \multicolumn{3}{|c|}{ Rata-rata } & $26,16 \%$ & Sedang \\
\hline
\end{tabular}

Sumber : Badan Pendapatan Daerah, Badan Pengelola Keuangan dan aset Daerah Provinsi Sulawesi Tenggara, Data diolah 2020

Tabe di atas menunjukan kontribusi BBNKB dalam meningkatkan PAD di Prov. Sultra yaitu berkontribusi sebesar 27,29\% untuk tahun 2016 dengan kriteria sedang, tahun 2017 penerimaan BBNKB mengalami penurunan dengan berkontribusi sebesar 22,18\% termasuk kriteria sedang, tahun 2018 kontribusi BBNKB juga masuk dalam kriteria sedang yaitu $28,00 \%$, dan pada tahun 2019 kontribusinya sebesar 27,15\% termasuk dalam kriteria sedang,

\section{Pembahasan}

Penerimaan Pajak kendaraan bermotor dan Bea Balik Nama Kendaraan Bermotor dalam Meningkatkan PAD di Provinsi Sulawesi Tenggara. Berdasarkan dari hasil analisis olahan data pada tabel di atas terlihat bahwa pajak kendaraan bermotor (PKB) dari tahun 2016-2019 memberika kontribusi dalam meningkatkan PAD di Provinsi Sulawesi Tenggara yaitu pada tahun 2016 PKB memberikan kontribusi sebesar 13,48\% dengan kriteria kurang, artinya kontribusi yang diberikan PKB tahun 2016 masih kurang partisipasinya dalam meningkatkan PAD. Tahun 2017 penerimaan PKB mengalami peningkatan dengan berkontribusi sebesar 17,41\% akan tetapi peningkatan tersebut masih dalam kriteria kurang, artinya tahun 2017 kontribusi PKB juga belum sepenuhnya memberikan kotribusi yang baik terhadap peningkatan PAD. Tahun 2018 pajak kendaraan bermotor mengalami penurun kontribusi sebesar 14,80\% termasuk dalam kriteria kurang, artinya tahun 2018 PKB juga masih sangat kurang memberikan sumbangsi dalam meningkatkan PAD. Sedangkan pada tahun 2019 kontribusi yang diberikan sebesar 14,09\% termasuk dalam kriteria kurang, artinya di tahun 2019 PKB masih belum memberikan kontribusi yang baik dalam peningkatan pendapatan asli daerah di Provinsi Sulawesi Tenggara.

Hal menunjukan bahwa pajak kendaraan bermotor (PKB) dari tahun 2016-2019 memberika kontribusi dalam meningkatkan PAD di Provinsi Sulawesi Tenggara yaitu dengan rata-rata $14,95 \%$ termasuk dalam kriteria kurang. Artinya dalam empat tahun terakhir penerimaan pajak kendaraan bermotor belum optimal dalam pemungutannya dan belum sepenuhnya memberikan kontrubusi yang baik dalam meningkatkan PAD di Provinsi Sulawesi Tenggara.

Sedangkan hasil olahan data untuk Bea Balik Nama Kendaraan Bermotor (BBNKB) dari tahun 2016-2019 yaitu berkontribusi sebesar 27,29\% untuk tahun 2016 dengan kriteria sedang, artinya realisasi BBNKB yang diterima pada tahun 2016 sudah memberikan kontribusi yang cukup baik dalam penerimaan PAD. Tahun 2017 penerimaan BBNKB mengalami penurunan dengan berkontribusi sebesar $22,18 \%$ termasuk kriteria sedang, artinya realisasi yang diterima tahun 2017 mengalami penurunan pendapatan yang mengakibatkan rendahnya kontribusi yang diberikan terhadap penerimaan PAD. Tahun 2018 kontribusi BBNKB juga masuk dalam kriteria sedang yaitu 28,00\%, artinya BBNKB 
di tahun 2018 berkontribusi lebih baik dari tahun sebelumnya yang berarti memberikan sumbangsi lebih terhadap peningkatan PAD. Pada tahun 2019 kontribusinya sebesar 27,15\% termasuk dalam kriteria sedang, artinya di tahun 2019 kontribusi BBNKB yang diberikan terhadap peningkatan PAD tidak jauh berbeda dengan tahun-tahun sebelumnya.

Hal ini menunjukan bahwa kontribusi bea balik nama kendaraan bermotor dalam meningkatkan pendapatan asli daerah dalam kurun waktu 2016-2019 dengan rata-rata yaitu $26,16 \%$ termasuk dalam kriteria sedang. Artinya dalam empat tahun terakhir penerimaan bea balik nama kendaraan bermotor sudah memberikan kontribusi yang cukup baik terhadap pendapatan asli daerah di Provinsi Sulawesi Tenggara.

Pemungutan PKB dan BBNKB di Provinsi Sulawesi Tenggara memiliki beberapa hambatan diantaranya : kurangnya melakukan tindakan di lapangan atau sosialisasi dari pemeritah itu sendiri, kurangnya anggaran operasional contohnya seperti anggaran sweping. Disisi pelayanan menurut beberapa wajib pajak, kendala utama dalam membayar pajak kendaraan bermotor dan bea balik nama kendaraan bermotor adalah antrian panjang dan lama. Kurangnya kontribusi yang diberikan pajak kendaraan bermotor dalam meningkatkan pendapatan asli daerah di Provinsi Sulawesi Tenggara disebabkan karena :

1. Kurangnya kesadaran masyarakat itu sendiri dalam hal pembayaran pajak kendaraan, hal ini tentu mengakibatka pada rendahnya penerimaan pajak kendaraan bermotor.

2. Terjadinya penurunan dijenis-jenis kendaraan yang dipotensikan besar akan tetapi terjadi penurunan. Contohnya ketika pemerintah menentukan target pajak kendaraan bermotor itu melihat daripada realisasi tahun sebelumnya dan melihat juga dari tren pembelian kendaraan bermotor diperjenisnya.

3. Sistem pelayanan kurang optimal yang diberikan oleh setiap UPTB SAMSAT Wilayah yang ada di Provinsi Sulawesi Tenggara.

Sedangkan untuk bea balik nama kendaraan bermotor penyebab rendahnya kontribusi karena :

1. Kurangnya pengetahuan masyarakat terhadap bea balik nama kendaraan bermotor itu sendiri.

2. Kesadaran masyarakat masih kurang, sehingga pembelian kendaraan bermotor cenderung membeli di daerah-daerah terdekat Sulawesi Tenggara seperti contohnya di Makassar maupun daerah Jawa. Dimana masyarakat melihat dari adanya perbedaan harga, tetapi mereka tidak menghitung biaya mobilisasi maupun mutasi kendaraan bermotor dari daerah asal terdaftar kendaraan tersebut.

3. Adanya peraturan Gubernur Sulawesi Tenggara Nomor 34 Tahun 2017 tentang pembebasan/keringanan bea balik nama kendaraan bermotor.

\section{Upaya Pemerintah Daerah Dalam Meningkatkan Penerimaan Pajak Kendaraan Bermotor dan Bea Balik Nama Kendaraan Bermotor}

Pemerintah daerah (BAPENDA Provinsi Sulawesi Tenggara selaku koordinator) dalam memperoleh penerimaan PKB dan BBNKB yaitu dengan melakukan strategi melalui beberapa kebijakan, seperti dari hasil wawancara dengan kepala bidang bagian pajak. Mengungkapkan, sejak tahun 2019 pemerintah telah mengeluarkan regulasi, bahwa kendaraan yang tidak membayar pajak kendaraan bermotor selama lima tahun, dianggap sebagai kendaraan bodong. Jika ditemukan kendaraan bermotor yang tidak membayar pajak kendaraannya selama 5 tahun berturut-turut, maka akan langsung dilakukan penyitaan dan pemusnahan, tanpa dititip lagi di pos polisi. Membuat time schedule dalam hal pelaksanaan razia/sweping diseluruh wilayah Unit Pelaksana Teknis Badan (UPTB), membangun kantor UPTB pengelolaan pendapatan daerah di daerah-daerah kabupaten baru yang belum memiliki kantor UPTB sehingga sistem pelayaan publik dapat dijangkau oleh masyarakat lebih cepat. Contohnya pembangunan kantor baru UPTB Buton Selatan. 
Pemerintah daerah, khususnya BAPENDA selalu melakukan upaya untuk meningkatkan pendapatan daerah khususnya pajak kendaraan bermotor dan bea balik nama kendaraan bermotor yaitu dengan mendata kendaraan yang kategori Kendaraan Tidak Melakukan Daftar Ulang (KTMDU), mensosialisasikan kepada masyarakat dalam hal pembelian kendaraan bermotor agar membeli di wilayah sulawesi tenggara, mensosialisasikan agar kendaraan yang belum DT agar memutasi kendaraannya di wilayah asal kendaraan agar pindah di wilayah domisili kendaraan.

\section{Kesimpulan}

\section{KESIMPULAN DAN SARAN}

Berdasarkan hasil penelitian dan pembahasan mengenai kontribusi PKB dan BBNKB dalam meningkatkan PAD di Provinsi Sulawesi Tenggara tahun 2016-2019, maka penulis dapat penyimpulkan bahwa : "Selama empat tahun penerimaan pajak dari 20162019 menunjukan bahwa Pajak Kendaraan Bermotor (PKB) masih kurang berkontribusi dalam meningkatkan pendapatan asli daerah dengan hanya berkontribusi sebesar $14,95 \%$ yang artinya termasuk dalam kriteria kurang berkontribusi. Hal ini di sebabkan karena kurangnya kesadaran masyarakat terhadap pembayaran pajak kendaraan, terjadinya penurunan dijenis-jenis kendaraan yang dipotensikan besar akan tetapi terjadi penurunan dan sistem pelayanan kurang optimal yang diberikan oleh setiap UPTB SAMSAT Wilayah yang ada di Provinsi Sulawesi Tenggara:.

Bea Balik Nama Kendaraan Bermotor (BBNKB) dari tahun 2016-2019 memberikan kontribusi dalam meningkatkan $\mathrm{PAD}$ dengan rata-rata yaitu $26,16 \%$ termasuk dalam kriteria Sedang. Artinya dalam empat tahun terakhir penerimaan bea balik nama kendaraan bermotor sudah memberikan kontribusi yang cukup baik terhadap PAD di Provinsi Sulawesi Tenggara. Namun pada tahun 2017 BBNKB memberikan kontribusi paling rendah terhadap penerimaan PAD yaitu berkontribusi sebesar 22,18\%. Hal ini disebabkan dengan adanya peraturan Gubernur Sulawesi Tenggara Nomor 34 Tahun 2017 tentang pembebasan/keringanan bea balik nama kendaraan bermotor.

\section{Implikasi}

Berdasarkan kesimpulan di atas, kontribusi pajak kendaraan bermotor dan beabalik nama kendaraan bermotor dalam meningkatkan Pendapatan Asli Daerah di provinsi sulawesi tenggara tahun 2016-2019 masih dalam kriteria kurang untuk PKB dengan ratarata $14,95 \%$ termasuk dalam kriteria kurang. Sedangkan untuk BBNKB rata-rata yaitu 26,16\% termasuk dalam kriteria sedang. Badan Pendapatan Daerah (BAPENDA) di Provinsi Sulawesi Tenggara dalam mengelola pendapatan asli daerah khsusnya dari PKB dan BBNKB yang dilakukan sudah cukup baik, namun diharapkan adanya komitmen untuk menjalankan hal tersebut dengan maksimal. Sehingga mampu lebih meningkatkan pendapatan pajak kendaraan bermotor dan bea balik nama kendaraan bermotor agar dapat memberikan kontribusi yang lebih besar dalam meningkatkan pendapatan asli daerah di Provinsi Sulawesi Tenggara.

\section{Keterbatasan Penelitian}

Penelitian ini memiliki beberapa keterbatasan antara lain sebagai berikut :

1. Objek penelitian ini terbatas hanya pada kontribusi pajak kendaraan bermotor dan bea balik nama kendaraan bermotor.

2. Penelitian dilakukan dengan data primer yang diperoleh melalui wawancara mendalam. Keterbatasan pada penelitian ini meliputi subyektifitas yang ada pada peneliti. Penelitian ini sangat tergantung kepada interprestasi peneliti tentang makna yang tersirat dalam wawancara sehingga kecenderungan untuk bias masih tetap ada. Untuk 
mengurangi bias maka dilakukan proses triagulasi sumber. Triagulasi sumber dilakukan dengan cara cross check data dengan fakta dari informan. .

\section{Rekomendasi}

Berdasarkan kesimpulan dari hasil penelitian penulis menyarankan :

3. Badan Pendapatan Daerah (BAPENDA) Provinsi Sulawesi Tenggara, perlu melakukan sosialisasi kepada masyarakatan terkait kewajiban pembayaran pajak kendaraan bermotor dan bea balik nama kendaraan bermotor, khususnya bagi masyarakat di daerah Kabupaten/Kota yang ada disetiap di wilayah tersebut. Dan juga perlunya lebih mensosialisasikan kebijakan yang dikeluarka pemerintah.

4. Pemerintah Daerah, khususnya BAPENDA lebih berupaya untuk meningkatkan penerimaan pajak kendaraan bermotor dan bea balik nama kendaraan bermotor dengan bekerja sama dengan SAMSAT disetiap UPTB wilayah-wilayah agar kedepannya akan tercapai penerimaan pajak kendaraan bermotor yang optimal sehingga dapat berkontribusi lebih baik dalam meningkatkan pendapatan asli daerah.

5. Kepada UPTB wilayah-wilayah di Provinsi Sulawesi Tenggara agar meningkatkan kualitas sistem pelayanan pembayaran pajak kendaraan bermotor agar dapat memberikan kepuasan kepada wajib pajak atau masyarakat setempat

\section{DAFTAR PUSTAKA}

Badan Pengelola Keuangan dan Aset Daerah Provinsi Sulawesi Tenggara. Data Penerimaan Pendapatan Asli Daerah Tahun 2016-2019.

Badan Pendapatan Daerah Sulawesi Tenggara. Data Jumlah Objek Kendaraan Bermotor Tahun 2016-2019.

.Target dan Realisasi Pajak Kendaraan Bermotor Dan Bea Balik Nama Kendaran Bermotor Tahun 2016-2019.

Direktorat Jendral Pajak. 2009. Undang-Undang Nomor 28 Tahun 2009, tentang Pajak Daerah dan Retribusi Daerah.

Halim, Abdul. 2004. Akuntansi Keuangan Daerah. Jakarta: Salemba Empat. STIM YKPN. .2008. Auditing (Dasar-dasar Laporan Keuangan). Yogyakarta: UPP

Handoko, T. Hani. 2013. Manajemen Edisi kedua. Yogyakarta: BPFE.

Mahmudi. 2010. Manajemen Keuangan Sektor Publik Edisi 2. Yogyakarta: Sekolah Tinggi Ilmu Manajemen (YKPN).

Mardiasmo. 2016. Perpajakan Edisi Terbaru 2016. Yogyakarta: Andi Offset.

Peraturan Gubernur Sulawesi Tenggara Nomor 10 Tahun 2019. Tentang Tata Cara Penyaluran Dana Bagi Hasil Pajak Provinsi Kepada Pemerintah Kabupaten/Kota Se Sulawesi Tenggara.

Radiah, ST. 2017. “Analisis Kontribusi Pajak Kendaraan Bermotor terhadap Pendapatan Asli Daerah Provinsi Sulawesi Selatan". Fakultas Ekonomi dan Bisnis Jurusan Akuntansi Universitas Hasanuddin Makassar.

Resmi, Siti. 2019. Perpajakan. Teori dan Kasus Edisi 11. Jakarta: Salemba Empat Waluyo. 2011. Perpajakan Indonesia. Jakarta: Salemba Empat. 